\title{
Differences in learners' critical thinking by ability level in conventional, NHT, PBL, and integrated NHT-PBL classrooms
}

\author{
Muhammad Rijal ${ }^{1}$, Ajeng Gelora Mastuti ${ }^{2}$, Dian Safitri ${ }^{3}$, Suhaedir Bachtiar $^{4}$, Salma Samputri ${ }^{5}$ \\ ${ }^{1,2}$ Institut Agama Islam Negeri Ambon, Maluku, Indonesia \\ ${ }^{3}$ Faculty of Teacher Training and Education, Universitas Muhammadiyah Makassar, Indonesia \\ ${ }^{4}$ Public Junior High School 2 Batang, South Sulawesi, Indonesia \\ ${ }^{5}$ Faculty of Mathematics and Natural Sciences, Universitas Negeri Makassar, Indonesia
}

\begin{tabular}{l}
\hline \hline Article Info \\
\hline Article history: \\
Received Dec 27, 2020 \\
Revised Aug 18, 2021 \\
Accepted Sep 10, 2021
\end{tabular}

Keywords:

Academic ability

Critical thinking

Factorial pattern

Learning models

\begin{abstract}
This study aimed to analyze the effect of conventional, Problem-Based Learning (PBL), Numbered-Head Together (NHT), and integrated PBL-NHT learning models on the low- and high-ability students' critical thinking. This quasi-experimental study used a pretest-post-test nonequivalent control group design with a four-by-two factorial pattern. The analysis results showed that learners' critical thinking was impacted by learning models implemented in the classroom and influenced by the interaction between the learning models and learners' academic abilities. There was no difference in critical thinking among low-ability students who were taught with PBL, conventional, and integrated PBL-NHT, but a difference was found in students taught using NHT. There was no difference in critical thinking between high-ability students taught with conventional and NHT instruction, but there was a difference between students taught with PBL and integrated PBL-NHT instruction. To foster critical thinking, pupils with low academic ability should be taught using NHT, whereas those with high academic ability should be taught using PBL or an integrated PBL-NHT approach.
\end{abstract}

This is an open access article under the CC BY-SA license.

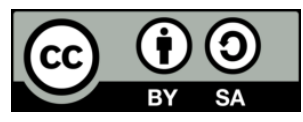

\section{Corresponding Author:}

Muhammad Rijal

Biology Education Program

Institut Agama Islam Negeri Ambon

Maluku, Indonesia

Email: rijal_rijal82@yahoo.co.id

\section{INTRODUCTION}

The condition is worsened by the fact that the senior high schools in Jeneponto district use new student recruitment system similar to that in universities. The student recruitment system, which is an activity to select prospective students to participate teaching and learning activities at schools, should be different from that in universities. Student recruitment must be marked with a selection process to ensure that the schools get excellent students who can participate the teaching and learning activities in school well based on the predetermined targets by the schools [1].

A student recruitment system in senior high schools that applies a minimal passing level (MPL) of national exam $(U A N)$ causes only prospective students with national exam scores higher than the determined minimal passing level who can be accepted in the target schools. Such system makes some particular schools get only the higher academic ability students, while some other schools get only the lower academic ability students [2]. 
The MPL-based student recruitment process results in the segregation of high academic ability and low academic ability students into separate institutions. As a result, it causes the emergence of high, medium, and even very low level schools [3], [4]. The low level schools are generally the schools that include the students who have low levels of thinking and metacognitive skills. In fact, thinking skills and metacognitive skills are a very fundamental element in the learning process. Students with superior academic skills have a more positive attitude about learning and study habits [4]. The high-ability students can also achieve higher academic life skills than the low-ability students can do [5].

This polarization becomes a challenge for all teachers to continually empower the students' critical thinking skills and metacognitive skills [6]. Mahanal, et al. noted that the gaps between students with higher and lower academic abilities should be considered, and it was predicted that the gaps would close over time as the learning process and outcomes improved [7]. As a result, it is essential to find a learning model which has the potential and bigger chance of empowering the critical thinking skills of the low-ability students [8].

The teachers' current instructional strategies do not fully optimize their pupils' critical thinking and metacognitive skills. As a result, students' critical thinking in biology remained low. Numerous research findings indicate that pupils in Indonesia lack the ability to engage in critical and higher-order thinking [9]. Mahanal, et al. stated that the empowerment of thinking was practically never/very seldom noticed and utilized in Indonesian classrooms [7]. Not only does critical thinking involve the ability to recall knowledge, but it also demands the ability to engage in higher-order reasoning. As a result, critical thinking skills should be developed throughout the learning process [9]. Students' lack of critical thinking skills is created indirectly by the educational process, which has not yet empowered students' thinking skills [1], [10].

Biology is a subject taught at the senior high school level. To comprehend the learning content provided in Biology, higher-order thinking is required. Mahanal, et al. asserted that the failure of Biology learning was attributable not just to students' limited prior knowledge, but also to the learning model's inability to increase students' critical thinking skills. This eventually resulted in the students' low cognitive learning scores. Biology education is supposed to develop human resources capable of competing in the global digital era through cognitive changes, namely through the development of critical thinking skills [7].

Students' critical thinking skills must be fostered in order for them to generate fresh ideas and alternative answers. Equipping children with the ability to think critically will boost their mental activity [11]. Students who possess strong critical thinking skills will be able to reason, draw inferences, make decisions, define problems clearly [12], collect and evaluate pertinent information, apply abstract concepts, be receptive to new ideas, and communicate effectively with other individuals [5]. Critical thinking skills development is critical since information acquisition is a cognitive process and mental activity. Students develop critical thinking skills in the classroom through challenging assumptions, identifying and participating in rigorous conversation and self-discipline [13].

Teachers can strengthen students' critical thinking skills by employing constructivism-based learning models that engage students in active knowledge seeking and construction. Problem-Based Learning (PBL) and Numbered-Head Together (NHT) are two constructivism-based learning approaches. According to Masek and Yamin, PBL is an effective model for developing students' critical thinking skills [14]. PBL can help students develop into inquirers, problem solvers, critical thinkers, and creative thinkers capable of overcoming complicated obstacles [15].

Along with PBL, the learning model deemed appropriate for developing critical thinking skills is NHT. NHT is one of the instructional approaches that can be utilized to engage students in active teaching and learning. NHT can be regarded as a teacher's endeavor to engage pupils in the process of teaching and learning [16]. NHT puts a focus on group work over individual work, ensuring that students collaborate and have numerous opportunities to distribute information and build communication skills [17].

Prayitno, et al. studied the NHT model's potential for boosting the critical thinking skills of lowability pupils [9]. In general, the study found that low-ability students' critical thinking skills were improving. Leasa and Corebima also reported that NHT could accommodate students' different academic abilities [4]. NHT is an excellent instructional technique for increasing students' motivation and enhancing students' critical thinking skills [1], [18], [19].

By using NHT in the classroom, it is believed that low-ability students will increase the quality of their learning and thinking abilities, particularly critical thinking. Additionally, the difference between pupils with poorer and higher academic abilities can be narrowed. According to research, teachers should apply NHT to help low-ability students develop their critical thinking skills while they wait for a new student recruitment system that no longer relies on the MPL system. 


\section{RESEARCH METHOD}

\subsection{Research design}

This research is a quasi-experimental research of pretest-postest nonequivalent control group design in $4 \times 2$ factorial design. The independent variable positioned as A factor is the integration of PBL+NHT, PBL, NHT model, and conventional learning, while positioned as B factor is the upper and the lower academic ability [1], [9]. The dependent variable is critical thinking skills as shown in Table 1.

Table 1. Quasi experimental research of $4 \times 2$ factorial design

\begin{tabular}{ccccc}
\hline \multirow{2}{*}{ Academic ability } & \multicolumn{4}{c}{ Learning model (S) } \\
& PBL (S1) & NHT (S2) & PBL+NHT (S3) & Conventional (S4) \\
\hline Upper (K1) & S1K1 & S2K1 & S3K1 & S4K1 \\
Lower (K2) & S1K2 & S2K2 & S3K2 & S4K2 \\
\hline
\end{tabular}

\subsection{Population and sample}

The population for this study was comprised of all tenth grade students enrolled in the even semester of the 2018/2019 academic year at 11 Senior High Schools in the Jeneponto, South Sulawesi, Indonesia. Random sampling technique was used to choose the samples. SMAN 1 Binamu, SMAN 2 Binamu, SMAN 1 Batang, and SMAN 1 Tamalatea were chosen as research samples. According to the results of placement tests conducted using the data from the grouping test, all participants were equal in terms of academic ability. The placement test results were evaluated using analysis of variance (ANOVA) in conjunction with the SPSS 20.0 application for Windows. Each experimental class was divided into three academic ability levels, namely upper, middle, and lower. The research subjects were students with a higher academic ability (33.3\%) and those with a lower academic ability (33.3\%) from each class. The syllabus, lesson plans $(R P P)$, and student worksheets $(L K S)$ were all employed in this study. This study was conducted for 12 meetings and covered eight basic competencies in biology. Table 2 summarizes the distribution of the research samples.

Table 2. Distribution of research samples in each group

\begin{tabular}{|c|c|c|c|c|}
\hline Experimental class & Sample & Academic ability & $\mathrm{N}$ & Total \\
\hline \multirow{2}{*}{ NHT } & \multirow{2}{*}{ Senior High School 1 Tamalatea } & Upper & 24 & \multirow{2}{*}{48} \\
\hline & & Lower & 24 & \\
\hline \multirow{2}{*}{ PBL } & \multirow{2}{*}{ Senior High School 1 Batang } & Upper & 25 & \multirow{2}{*}{50} \\
\hline & & Lower & 25 & \\
\hline \multirow{2}{*}{$\mathrm{PBL}+\mathrm{NHT}$} & \multirow{2}{*}{ Senior High School 1 Batang } & Upper & 25 & \multirow{2}{*}{50} \\
\hline & & Lower & 25 & \\
\hline \multirow{3}{*}{ Conventional } & \multirow{2}{*}{ Senior High School 2 Binamu } & Upper & 25 & \multirow{2}{*}{50} \\
\hline & & Lower & 25 & \\
\hline & Total sample & & & 98 \\
\hline
\end{tabular}

\subsection{Research instruments}

The study collected data through the use of an integrated academic and critical thinking test that assessed participants' cognitive learning outcomes and critical thinking skills in Biology. The results on critical thinking were examined using a rubric devised by Mahanal, et al. based on Finken and Ennis's scale of 0 to 5 [7].

The research instruments were validated by four experts and then followed with revision, try out of the Biology cognitive learning result test integrated with critical thinking skill test, and readability test of the student worksheet by the students. The results of the try out of the Biology cognitive learning results test integrated with critical thinking skill test are used as the basis for determining the validity and reliability of the test. This stage resulted in the creation of validated learning materials that were then used in the experimental research.

\subsection{Data collection and analysis}

Data were collected prior to and following the learning process. The data were analyzed using twoway ANCOVA at a 5\% level of significance. SPSS 20.0 for Windows was used to analyze the data. If the ANCOVA test yielded significant results, the Least Significant Difference (LSD) test would be performed. Prior to doing the ANCOVA analysis, assumption tests, specifically normality and homogeneity tests, were conducted. One-Sample Kolmogorov-Smirnov method was used to test the data normality, while Levene's Test of Error Variance Equality was employed in the homogeneity test. 


\section{RESULTS AND DISCUSSION}

3.1. Results

\subsubsection{Findings on hypothesis testing of the students' critical thinking skills}

Table 3 summarizes the results of the ANCOVA test regarding the effect of learning models and academic ability on students' critical thinking skills. The results of ANCOVA presented in Table 3 show that the $\mathrm{F}$ value of the learning model is 5.249 ( $\mathrm{p}$-value=0.002). This suggests that learning models have an effect on students' ability to demonstrate critical thinking. While the F value of the interaction between the learning model and academic ability was 3.547 ( $p$-value=0.016), the $F$ value of the interaction between the learning model and academic ability was 3.547. Thus, there was a distinction in critical thinking skills as a result of the interaction between the learning model and academic ability.

Table 3. ANCOVA results related to the effect of learning model and academic ability on students' critical thinking skills

\begin{tabular}{cccccc}
\hline Source & Sum of squares & Df & Mean square & F & Sig. \\
\hline Corrected model & $25772.043^{\mathrm{a}}$ & 8 & 3221.505 & 23.339 & .000 \\
Intercept & 12943.185 & 1 & 12943.185 & 93.769 & .000 \\
Xcritical & 7797.559 & 1 & 7797.559 & 56.491 & .000 \\
Model & 2173.680 & 3 & 724.560 & 5.249 & .002 \\
Academic ability & 5722.863 & 1 & 5722.863 & 41.460 & .000 \\
Model * Academic ability & 1468.726 & 3 & 489.575 & 3.547 & .016 \\
Error & 26088.045 & 189 & 138.032 & & \\
Total & 455917.485 & 198 & & & \\
Corrected total & 51860.088 & 197 & & & \\
\hline
\end{tabular}

a. R Squared=.497 (Adjusted R Squared=.476)

\subsubsection{Findings on the differences in the interaction between learning model and academic ability toward critical thinking skills}

Table 4 summarizes the LSD test results regarding the effect of the interaction between the learning model and academic ability on critical thinking skills. As shown in Table 4, there was no difference in critical thinking skills between low-ability students taught using PBL, conventional, or integrated PBL-NHT instruction, however there was a difference for students taught using the NHT learning model. The critical thinking abilities of low-ability pupils did not differ between NHT and integrated PBL-NHT instruction. Additionally, it was discovered that there was no difference in critical thinking skills between upper-skilled students taught using conventional and NHT models, but there was a difference between students taught using PBL and integrated PBL-NHT models. The critical thinking skills of high-ability students did not differ between NHT, PBL, and integrated PBL-NHT instruction.

Table 4. Summary of LSD test related to the effect of the interaction between learning model and academic ability toward critical thinking skills

\begin{tabular}{cccccccc}
\hline Learning model & Academic ability & Pretest & Posttest & Differences & Corrected mean & Increase (\%) & LSD notation \\
\hline PBL & Lower & 18.81 & 32.50 & 13.69 & 36.30 & 72.78 & $\mathrm{a}$ \\
Conventional & Lower & 18.75 & 32.52 & 13.77 & 36.37 & 73.44 & $\mathrm{a}$ \\
PBL+NHT & Lower & 20.04 & 39.13 & 19.09 & 41.92 & 95.26 & $\mathrm{ab}$ \\
Conventional & Upper & 22.64 & 42.64 & 19.99 & 43.31 & 88.30 & $\mathrm{~b}$ \\
NHT & Lower & 27.52 & 47.04 & 19.52 & 43.74 & 70.93 & $\mathrm{~b}$ \\
NHT & Upper & 32.07 & 55.92 & 23.84 & 48.89 & 74.34 & $\mathrm{bc}$ \\
PBL & Upper & 26.31 & 57.36 & 31.04 & 55.03 & 11.78 & $\mathrm{c}$ \\
PBL+NHT & Upper & 22.09 & 54.80 & 32.71 & 55.92 & 148.18 & $\mathrm{c}$ \\
\hline
\end{tabular}

The findings of this study indicate that lower-ability pupils who learned utilizing NHT increased their critical thinking skills. Low-ability pupils may even achieve the same level of critical thinking as highability students. This suggests that the NHT learning model has the potential to help low-ability pupils develop their critical thinking skills. This is possible because NHT is effective in motivating students to learn, stimulating and enhancing their academic abilities, and providing opportunity for students to work in diverse groups [8]. According to Haydon, Maheady, and Hunter, numerous learning models can be utilized to actively engage students in the learning process, one of which is NHT [16]. The NHT learning model has an effect on students' learning outcomes [3]. 


\subsection{Discussion}

NHT is a cooperative learning model that enables students to exchange information in order to solve difficulties [20]. According to Shimazoe and Aldrich, cooperative learning can encourage students to become more receptive to learning and actively participate in the learning process [21]. Students' engagement in the learning process is a critical component affecting their learning outcomes. Lince's research indicated that implementing NHT had an effect on students' creative and active thinking during the learning process [19].

The development of the students' critical thinking skills cannot be separated from the role of the NHT learning model implemented by the teachers. The NHT learning model, particularly in the stage of heads together, has a positive effect and more effectively helps lower academic ability students. Discussion with group members about the results of observations can develop the students' thinking patterns. Students' critical thinking skills are empowered during the conclusion stage, that is connecting the concepts with the real situation [22]. According to Brookfield, one of the criteria that students use their critical thinking is that they can clarify opinions using relevant sources, and they can conclude an idea from different perspectives. Thus, in the conclusion stage of NHT learning model, the students are required to be able to relate their opinions and apply concepts with a real situation, so that they can make a stronger final conclusion [10]

According to the LSD notation, the critical thinking skills of low-ability students taught with NHT improved and even equalized those of high-ability students (notation b). According to Ghaith, pupils with lower academic competence are more at ease working in small groups [23]. The NHT learning model is extremely beneficial and simple to develop and utilize by teachers.

According to Bachtiar, et al., basically every student already has the potential or ability that can be developed related to the learning materials, but the level of ability of each student is not the same [1]. Thus, there are still some efforts that can be done to equalize the academic achievement of the lower academic ability students and the upper academic ability students. Previous studies found that some learning models had a high potential for improving the thinking skills of students with higher academic abilities and significantly improving the ability of students with lower academic abilities. The research findings revealed that experimenting with different learning models is one way to improve the learning outcomes of all students, regardless of their academic level [7], [9].

The difference in percentages of low- and high-ability students' critical thinking progress in NHT classrooms was smaller $(3.41 \%)$ than the difference in percentages of low- and high-ability students' critical thinking improvement in PBL, integrated PBL-NHT, and conventional groups. NHT learning model is easy to be implemented in the learning process [17], so that achieving learning objectives and improving critical thinking processes become easier. The steps of NHT are so simple that students can understand it easily, so it can optimize learning. Simple learning processes are essential in order to relieve students of unnecessary burdens and to allow them to focus on the learning topic and develop concepts effectively [24].

NHT is one of the learning models that can make students more interactive to share ideas in group discussions. NHT learning model provides an opportunity for each student to work individually and cooperatively with others [4], [25]. By selecting a number randomly, each student must prepare their answers. This can also motivate the students in learning [26]. Slavin suggested that cooperative learning was a learning process in which students worked together to help each other in a group [27]. Prayitno, et al. said that cooperative learning helped students to improve their cognitive and affective abilities [9].

The NHT learning model has the potential to elevate low-ability students' critical thinking to the level of high-ability pupils. According to Muhlisin, et al., students' critical thinking skills improve when cooperative learning models are used [25]. Critical thinking activities entail an individual performing, applying, analyzing, synthesizing, or evaluating information [28].

The current study's findings indicate that students' critical thinking skills differed when they were exposed to four various learning models: PBL, NHT, integrated PBL-NHT, and conventional. These findings verified Demirel and Arslan's assertion that learning models had the ability to boost students' critical thinking skills. Additionally, these findings suggest that students' metacognitive abilities can be strengthened by education, training, and habituation [29].

These self-regulation skills are very important for students [30]. Shetty found that PBL was effective in improving students' critical thinking skills. More specifically, they proved that PBL was able to help students extend their procedural knowledge, cognition knowledge, and planning and information management skills [31]. On a different occasion, Leasa and Corebima also showed the importance of applying NHT in learning. They reported that students' academic abilities can be accommodated in NHT. Therefore, the integrated PBL and NHT learning model can be assumed as the best combination of learning models that can improve students' metacognitive skills despite the differences in their academic abilities (upper and lower) [4].

The combination of PBL and NHT provides a stimulus for students' behavior construction. This learning model can help promote students' classroom interaction and attitude development [1]. PBL is an 
innovative learning model that is also useful in students' critical thinking skills, while NHT emphasizes students' active contribution in discussion. In NHT, every student is responsible to present their knowledge as an individual [7], [32].

The learning steps also highlight the potential of the integrated PBL and NHT learning models for developing students' critical thinking skills. The syntax of PBL and NHT encourages students to do an investigation either individually or in groups through discussion [33]. Needless to add, problem-based learning exercises can drive students to process their cognition autonomously prior to attempting to solve presented problems [5], [32].

While critical thinking is defined as thinking in order to think, metacognition is defined as more than just cognitive processes [34]. Some experts believe that metacognition is not a mere personal internal activity; it is a social process [1]. However, an independent student must be vigilant, observant, introspective, and analytic when accomplishing a work [29]. Apart from critical thinking skills, there are several other variables that can affect pupils' academic progress. Nonetheless, pupils' mastery of critical thinking skills reflects their capacity to learn other skills as well [35]. According to Dunning, et al., metacognition is a significant independent variable associated with academic success [36]. As a result, pupils who receive adequate training in metacognitive skills will achieve greater academic success. According to Prayitno, et al., the empowerment of students' metacognitive skills and critical thinking will impact the students' ability in a positive way [9].

In comparison to conventional learning models, cooperative learning models have been shown to improve students' academic performance. Additionally, cooperative learning models can help reduce the disparity between pupils with superior academic performance and those with inferior academic ability [9]. One of the cooperative learning models' objectives is teamwork [37]. Working in a team to solve problems also helps students develop collaborative and cooperative learning skills. Therefore, the integrated PBL and NHT can assist students in learning new knowledge and skills relevant to their daily life issues.

\section{CONCLUSION}

Students' critical thinking skills are impacted by conventional, PBL, NHT, and integrated PBL-NHT learning models. Students' critical thinking skills are also influenced by the combination between learning models and academic abilities. There was no difference in critical thinking skills between low-ability students taught using the PBL, conventional, or the integrated PBL-NHT learning models, however there was a difference for students taught using NHT. There was no difference in critical thinking skills between highability students taught using conventional and NHT models, but there was a difference between students taught using PBL and integrated PBL-NHT models. Students with low ability should be taught using the NHT learning model, whereas students with high ability should be taught using the PBL or integrated PBLNHT learning models.

\section{ACKNOWLEDGEMENTS}

The authors would like to express their heartfelt appreciation to the institutions that assisted in the completion of this study, specifically Universitas Negeri Malang (UNM), IAIN Ambon, UNISMUH Makassar, and the Head of the Jeneponto Education Office.

\section{REFERENCES}

[1] S. Bachtiar, S. Zubaidah, A.D. Corebima, and S. E. Indriwati, "The spiritual and social attitudes of students towards integrated problem based learning models," Issues in Educational Research, vol. 28, no. 2, pp. 254-270, 2018.

[2] Yusnaeni, A. D. Corebima, H. Susilo, and S. Zubaidah, "Creative thinking of low academic student undergoing search solve create and share learning integrated with metacognitive strategy," International Journal of Instruction, vol. 10, no. 2, pp. 245-262, 2017.

[3] W. C. Hunter, L. A. Dieker, and T. Whitney, "Consultants and coteachers affecting student outcomes with numbered heads together: Keeping all engaged,” J. Educ. Psychol. Consult., vol. 26, no. 2, pp. 186-199, 2016.

[4] M. Leasa and A. D. Corebima, "The effect of numbered heads together (NHT) cooperative learning model on the cognitive achievement of students with different academic ability," J. Phys.: Conf. Ser., vol. 795, pp. 1-9, 2017.

[5] R. Duron, B. Limbach, and W. Waugh, "Critical thinking framework for any discipline," International Journal of Teaching and Learning in Higher Education, vol. 17, no. 2, pp. 160-166, 2006.

[6] J. Papilaya, P. Tuakora, and M. Rijal, "Compensation, transparency, and motivation effects on the performance of junior high school teachers in Western Seram, Indonesia," Int. J. Instruct., vol. 12, no. 3, pp. 1-20, 2019

[7] S. Mahanal, S. Zubaidah, A. Bahri, and M. S. Dinnurriya, "Improving students' critical thinking skills through Remap NHT in biology classroom," Asia-Pacific Forum Sci. Learn. Teach., vol. 17, no. 2, pp. 1-19, 2016. 
[8] R. Harianda, F. Ras, and Supriusman, "Using Number Head Together (NHT) Strategy to Improve the Ability of the Second Year Students of MTs Ann Najah Pekanbaru in Writing Recount Texts," Academic Journal, pp. 1-10, 2013. [Online]. Available: http://repository.unri.ac.id:80/handle/123456789/4886.

[9] B. A. Prayitno, A. D. Corebima, H. Susilo, S. Zubaidah, and M. Ramli, "Closing The Science Process Skills Gap Between Students With High and Low Level Academic Achievement," Journal of Baltic Science Education, vol. 16, no. 2, pp. 266-277, 2017.

[10] S. Brookfield, Teaching for Critical Thinking: Tools and Techniques to Help Students Question Their Assumptions. San Fransisco, Jossey-Bass, 2012.

[11] P. A. Facione, "Critical thinking: What it is and why it counts," Insight Assessment, pp. 1-29, 2015.

[12] S. Zubaidah, S. Mahanal, Mistianah, and A. Fauzi, "Critical Thinking Embedded Essay Test," International Conference on Biology, Sciences and Education (ICoBioSE), 2019, doi: 10.2991/absr.k.200807.036.

[13] C. Sereni-Massinger, and N. Wood, "Teaching strategies for critical thinking skills," Academic Exchange Quarterly, vol. 19, no. 3, pp. 1-6, 2015. [Online]. Available: http://rapidintellect.com/AEQweb/5637z5.pdf.

[14] A. Masek and S. Yamin, "The effect of problem based learning on critical thinking ability: A theoretical and empirical review," International Review of Social Sciences and Humanities, vol. 2, no. 1, pp. 215-221, 2011.

[15] B. R. Belland, B. F. French, and P. A. Ertmer, "Validity and problem-based learning research: A review of instruments used to assess intended learning outcomes," IJPBL, vol. 3, no. 1, pp. 59-89, 2009.

[16] T. Haydon, L. Maheady, and W. Hunter, "Effects of numbered heads together on the daily quiz scores and on-task behavior of students with disabilities," J. Behav. Educ., vol. 19, no. 3, pp. 222-238, 2010.

[17] S. Kagan, Cooperative Learning Resources for Teacher. Jakarta, Intuisi Press, 2007.

[18] M. Maman and A. A. Rajab, "The implementation of cooperative learning model 'NumberHeads Together (NHT)' in improving the students' ability in reading comprehension," International Journal of Evaluation and Research in Education (IJERE), vol. 5, no. 2, pp. 174-180, 2016.

[19] R. Lince, "Creative thinking ability to increase student mathematics of junior high school by applying models numbered heads together," Journal of Education and Practice, vol. 7, no. 6, pp. 206-212, 2016.

[20] D. I. Oludipe, "Gender difference in Nigerian junior secondary students' academic achievement in basic science," Journal of Educational and Social Research, vol. 2, no. 1, pp. 93-99, 2012.

[21] J. Shimazoe and H. Aldrich, "Group work can be gratifying: understanding \& overcoming resistance to cooperative learning," College Teaching, vol. 58, no. 2, pp. 55-57, 2010.

[22] H. Widyaningtyas, R. Winarni, and T. Murwaningsih, "Teachers' obstacles in implementing numbered head together in social science learning," International Journal of Evaluation and Research in Education (IJERE), vol. 7, no. 1, pp. 25-31, 2018.

[23] G. Ghaith, "Learners' perceptions of their STAD cooperative experience," System, vol. 29, no. 2, pp. 289-301, 2001.

[24] H. Kolayis, I. Sari, and N. Celik, "The comparison of critical thinking and problem solving disposition of athletes according to gender and sport type," International Journal of Human Sciences, vol. 11, no. 2, pp. 842-849, 2014.

[25] A. Muhlisin, H. Susilo, M. Amin, and F. Rohman, "Improving critical thinking skills of college students through RMS model for learning basic concepts in science," Asia-Pacific Forum Sci. Learn. Teach., vol. 17, no. 1, 2016.

[26] Y. H. Riyanto, "Using numbered heads together to improve the student's reading comprehension in narrative text," Journal of Research \& Method in Education, vol. 7, no. 2, pp. 107-114, 2017, doi: 10.9790/7388-070202107114.

[27] R. Slavin, Cooperative Learning Theory, Research and Practice. Massachusett USA: Allymand \& Bacon, 1995.

[28] L. G. Snyder and M. J. Snyder, "Teaching critical thinking and problem solving skills," Delta Pi Epsilon Journal, vol. 50, no. 2, pp. 90-99, 2008.

[29] M. Demirel and B. Arslan-Turan, "The effects of problem-based learning on achievement, attitude, metacognitive awareness and motivation," Hacettepe Universitesi Egitim Fakultesi Dergisi-Hacettepe University Journal of Education, vol. 38, pp. 55-66, 2010.

[30] B. C. Howard, S. McGee, R. Shia, and N. S. Hong, "The influence of metacognitive self-regulation and ability levels on problem-solving," in American Educational Research Association. Seattle. Washington, 2001.

[31] G. A. Shetty, "Study of the effectiveness of problem based learning in developing metacognitive skills in student teachers," Thesis, SNDT University, India, 2008. [Online]. Available: http://hdl.handle.net/10603/110025.

[32] E. D. Graaf and A. Kolmos, "Characteristics of problem-based learning," Int. J. Eng. Educ, vol. 19, no. 5, pp. 657-662, 2003. [Online]. Available: https://www.ijee.ie/articles/Vol19-5/IJEE1450.pdf.

[33] S. G. Paris and A. H. Paris, "Classroom applications of research on self regulated learning," Educ Psychol., vol. 36, no. 2, pp. 89-101, 2001.

[34] P. Sharma and M. Hannafin, "Scaffolding critical thinking in an online course: An exploratory study," Journal of Educational Computing Research, vol. 31, no. 2, pp. 181-208, 2004.

[35] B. J. Zimmerman, "Becoming a self-regulated learner: An overview," Theory Into Practice, vol. 41, no. 2, pp. 64-70, 2002.

[36] D. Dunning, K. Johnson, J. Ehrlinger, and J. Kruger, "Why people fail to recognize their own incompetence," Current Directions in Psychological Science, vol. 12, no. 3, pp. 83-87, 2003.

[37] S. Turan, A. Konan, Y. A. Kilic, E. B. Ozvaris, and I. Sayek, "The effect of problem-based learning with cooperative-learning strategies in surgery clerkships," J. Surg. Educ., vol. 69, no. 2, pp. 226-230, 2012. 